\title{
Purification and characterisation of haemagglutinin from Bordetella bronchiseptica
}

\author{
Y. SAKURAI, H. SUZUKI* and E. TERADA* \\ Musashino Research Institute for Immunity Co. Ltd, 31-7 Shinjuku, 1-Chome, Shinjuku-ku, Tokyo 160 and "School \\ of Hygienic Sciences, Kitasato University, 1-15-1 Kitasato, Sagamihara-shi, Kanagawa 228, Japan
}

\begin{abstract}
Summary. A surface protein of Bordetella bronchiseptica was purified in one step by affinity chromatography with bovine submaxillary mucin coupled to agarose. The purified protein, with a mol. wt of $200 \mathrm{kDa}$ and an iso-electric point of $\mathrm{pI} 6.5$, showed haemagglutinating activity for bovine erythrocytes. This haemagglutinin (HA) inhibited the adherence of $B$. bronchiseptica to a rat lung cell line (L2) and was able to bind to $\mathrm{N}$-acetylneuraminic acid. These findings suggest that the HA of $B$. bronchiseptica is an adhesin.
\end{abstract}

\section{Introduction}

The mechanism of adherence of bacteria to the surface of fibroblasts or epithelial cells has been examined with many species and the presence of specific adhesins on the organisms and adhesin receptors on the cells has been demonstrated..$^{1-10}$

Adherence to the surface of epithelial cells in the respiratory tract and subsequent colonisation and proliferation at this site are considered to be necessary for Bordetella bronchiseptica to cause disease. ${ }^{11}$ Ishikawa et al..$^{12}$ suggested that the haemagglutinin (HA) of this organism might be a bacterial adhesin because a mutant strain, lacking HA activity, was incapable of adhering to the mammalian cell surface. B. pertussis appears to adhere to mammalian cells by a number of adhesins, namely filamentous haemagglutinin, pertussis toxin, pertactin and fimbrial agglutinogens, acting separately or together. ${ }^{13-16}$

Ishikawa et al. ${ }^{17}$ suggested that the adhesin receptors for $B$. bronchiseptica on mammalian cells were $N$ acetylneuraminic acid, and we obtained similar results in preliminary experiments. Ravindranath et al. ${ }^{18}$ purified a sialic acid-specific lectin from the serum of a marine crab, Cancer antennarius, by affinity chromatography. Thus, since the adhesin receptors of B. bronchiseptica are considered to be sialic acid and the adhesins are believed to have lectin-like binding properties, we believed that affinity chromatography could be useful for simple, rapid purification of the adhesin.

The purpose of this study was to attempt to purify the adhesin of $B$. bronchiseptica by affinity chromatography and examine its properties.

\section{Materials and methods}

\section{Bacterial strain}

B. bronchiseptica strain M-3, phase I, isolated from a guinea pig, ${ }^{19}$ was used for this study.

\section{Isolation of the crude surface proteins}

$B$. bronchiseptica was propagated on BordetGengou Agar (Difco) containing defibrinated sheep blood $7 \%$ for $48 \mathrm{~h}$ at $37^{\circ} \mathrm{C}$, collected in Dulbecco's

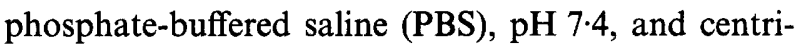
fuged twice at $10000 \mathrm{~g}$ for $10 \mathrm{~min}$. Carbonate buffer $(0.1 \mathrm{M}, \mathrm{pH} 9.8)$ was added to the washed cells to prepare a $10 \% \mathrm{w} / \mathrm{v}$ bacterial suspension. ${ }^{20.21}$ The suspension was heated in a water bath for $30 \mathrm{~min}$ at $37^{\circ} \mathrm{C}$ and centrifuged at $10000 \mathrm{~g}$ for $20 \mathrm{~min}$ at $4^{\circ} \mathrm{C}$. The supernate was dialysed overnight in $0.05 \mathrm{M}$ Tris$\mathrm{HCl}$ buffer, $\mathrm{pH} 7.5$, containing $0.1 \mathrm{M} \mathrm{NaCl}$ and $0.01 \mathrm{M}$ $\mathrm{CaCl}_{2}$ (TBS) to yield a preparation of crude surface proteins.

\section{Preparation of affinity medium}

Bovine submaxillary mucin (BSM; Sigma) was coupled to agarose by the technique of Ravindranath et al.$^{18}$ Affi-Gel 15 (BioRad Laboratories; $25 \mathrm{ml}$ ) was washed with cold distilled water and resuspended to $100 \mathrm{ml}$ in cold $0.05 \mathrm{M}$ HEPES buffer, $\mathrm{pH} 8.2$, containing $100 \mathrm{mg}$ of BSM. The reaction proceeded for $8 \mathrm{~h}$ at $4^{\circ} \mathrm{C}$, after which $5 \mathrm{ml}$ of $1 \mathrm{M}$ ethanolamine- $\mathrm{HCl}$, $\mathrm{pH} 8.0$, was added to block any remaining active sites. The adsorbent was washed with TBS and stored in TBS with sodium azide $0.02 \% \mathrm{w} / \mathrm{v}$ at $4^{\circ} \mathrm{C}$ until required. 


\section{Purification of the surface protein}

The crude extract of surface proteins $(2.5 \mathrm{ml})$ was applied to $2 \mathrm{ml}$ of TBS-equilibrated BSM-agarose in a glass column $(9 \times 50 \mathrm{~mm})$ fitted with a water jacket. The column was washed first with $0.05 \mathrm{M}$ Tris- $\mathrm{HCl}$ buffer, $\mathrm{pH} 7 \cdot 5$, containing $1 \mathrm{M} \mathrm{NaCl}$ and $0.01 \mathrm{M} \mathrm{CaCl}_{2}$ and then with $0.05 \mathrm{M}$ Tris- $\mathrm{HCl}$ buffer, $\mathrm{pH} 7 \cdot 5$, containing $0.3 \mathrm{M} \mathrm{NaCl}$ and $0.01 \mathrm{M} \mathrm{CaCl}_{2}$. The column was incubated for $10 \mathrm{~min}$ at $32^{\circ} \mathrm{C}$ and washed again with the same buffer. Elution was done at $32^{\circ} \mathrm{C}$ in $0.05 \mathrm{M}$ Tris- $\mathrm{HCl}$ buffer, $\mathrm{pH} 7 \cdot 5$, containing $0.3 \mathrm{M} \mathrm{NaCl}$ and $2 \mathrm{~mm}$ EDTA. Fractions of $1 \mathrm{ml}$ were collected into tubes, each containing $100 \mu \mathrm{l}$ of $0.1 \mathrm{M} \mathrm{CaCl}_{2}$, which were cooled rapidly in an ice bath. Each eluted fraction was concentrated to about one-tenth of its original volume for the assay of HA activity. The protein concentration was estimated by the method of Lowry et al. ${ }^{22}$

\section{Haemagglutination test}

Haemagglutination was assayed according to the technique of Ishikawa et al.$^{12}$ Each fraction was diluted in two-fold steps up to 1 in 64 in the wells of a Ubottomed microtitration plate (Falcon), followed by the addition of an equal volume $(25 \mu \mathrm{l})$ of bovine erythrocytes $0.5 \% \mathrm{v} / \mathrm{v}$. After mixing and incubation for $2 \mathrm{~h}$ at $37^{\circ} \mathrm{C}$, the haemagglutination titre was determined. One unit of activity was defined as the amount of protein required to give haemagglutination in one well. ${ }^{18}$

\section{SDS-PAGE and iso-electric focusing (IEF)}

SDS-PAGE was performed according to the method of $\mathrm{Laemmli}^{23}$ with 4-12\% gradient SDSpolyacrylamide gels (TEF Co., Nagano, Japan). For solubilisation, each sample was mixed in equal volumes with $20 \mathrm{~mm}$ Tris- $\mathrm{HCl}$ buffer, $\mathrm{pH} 6.8$, containing SDS $2 \% \mathrm{w} / \mathrm{v}$, mercaptoethanol $2 \% \mathrm{v} / \mathrm{v}$ and glycerol $40 \% \mathrm{v} / \mathrm{v}$, and the mixture was placed in a boiling water bath for $5 \mathrm{~min}$. Solubilised sample $(20 \mu \mathrm{l})$ was added to each lane of the gel for electrophoresis at $20 \mathrm{~mA}$. The mol. wt was estimated from the mobility of the marker proteins (High mol. wt range, Bethesda Research Laboratories).

The iso-electric point was determined by IEF-PAGE (TEF Co.) with a $\mathrm{pH}$ range of $3-10 .^{24}$ Each sample was mixed in equal volumes with glycerol $60 \% \mathrm{v} / \mathrm{v}$. The sample solution $(20 \mu \mathrm{l})$ was added to each lane for electrophoresis at $500 \mathrm{~V}$. The iso-electric point was estimated by comparison with marker proteins (Broad pI Calibration Kit, Pharmacia).

\section{Adherence inhibition assay}

The protein $(0.5 \mathrm{ml})$ purified in the BSM-agarose affinity columns was adjusted to 20,10 or $2 \mu \mathrm{g} / \mathrm{ml}$ with Hanks's balanced salts solution (HBSS) and added to rat lung cells (L2 cells) obtained by monolayer culture in eight-chamber slides (Lab-TeK ${ }^{\circledR}$; Nunc, Roskilde, Denmark) and allowed to react for $30 \mathrm{~min}$ at $37^{\circ} \mathrm{C}$. The reaction slide was washed with HBSS, to which $0.5 \mathrm{ml}$ containing $10^{8} \mathrm{~B}$. bronchiseptica cfu was added. The bacteria had been grown on Bordet-Gengou agar containing defibrinated sheep blood $7 \% \mathrm{v} / \mathrm{v}$ for $20 \mathrm{~h}$ at $37^{\circ} \mathrm{C}$. The slide was incubated for $30 \mathrm{~min}$ at $37^{\circ} \mathrm{C}$, after which it was washed with cold HBSS to eliminate non-adhering organisms and stained with MayGrünwald and Giemsa solution. The bacteria adhering to $20 \mathrm{~L} 2$ cells were counted by light microscopy $(1000 \times$ magnification). Data were expressed in terms of the mean number of attached bacteria/L2 cell. All assays were performed in triplicate.

\section{Examination of the receptor specificity of the purified protein}

$N$-Acetylneuraminic acid (NeuAc; 10,1 or $0.1 \mathrm{mg}$ ) was dissolved in a solution containing the purified protein at $10 \mu \mathrm{g} / 0.5 \mathrm{ml}$ and allowed to react for $30 \mathrm{~min}$ at $37^{\circ} \mathrm{C}$. The solution was then added to the $\mathrm{L} 2$ cells obtained by monolayer culture in eight-chamber slides followed by the procedure used for the adherence inhibition assay.

\section{Results}

\section{Purification of the surface protein}

Fig. 1 shows the elution profile of the surface protein obtained by BMS-agarose affinity chromatography. Each of the fractions obtained by the various elution conditions was concentrated to one-tenth of its original volume. The presence or absence of HA activity was determined by a haemagglutination assay with bovine erythrocytes. Haemagglutinating activity was

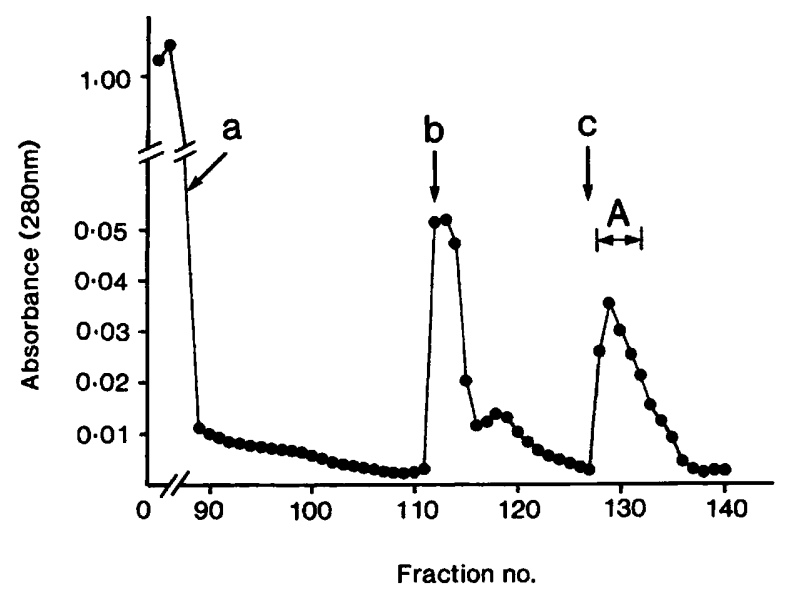

Fig. 1. Elution profile of affinity column. BSM-agarose was equilibrated with TBS containing of $10 \mathrm{mM} \mathrm{CaCl}_{2}$ at $4^{\circ} \mathrm{C}$. The crude protein extract was applied and the column washed with (a) TBS containing $1 \mathrm{M} \mathrm{NaCl}$ and $10 \mathrm{mM} \mathrm{CaCl}_{2}$ at $4^{\circ} \mathrm{C}$. The column was transferred to a water bath at $32^{\circ} \mathrm{C}$ and washed with (b) TBS containing $0.3 \mathrm{M} \mathrm{NaCl}$ and $10 \mathrm{mM} \mathrm{CaCl}_{2}$. (c) Elution was done at $32^{\circ} \mathrm{C}$ with TBS containing $0.3 \mathrm{M} \mathrm{NaCl}$ and $2 \mathrm{~mm}$ EDTA. Fractions of $1 \mathrm{ml}$ were collected and those containing haemagglutinating activity were pooled and designated as fraction $\mathbf{A}$. 
Table I. Purification of $B$. bronchiseptica strain M-3 surface protein

\begin{tabular}{lccccc}
\hline Step & $\begin{array}{c}\text { Volume } \\
(\mathrm{ml})\end{array}$ & $\begin{array}{c}\text { Protein } \\
(\mathrm{mg})\end{array}$ & $\begin{array}{c}\text { Total } \\
\text { activity* } \\
\text { (HA units) }\end{array}$ & $\begin{array}{c}\text { Specific } \\
\text { activity } \\
\text { (HA units/mg) }\end{array}$ & $\begin{array}{c}\text { Purification } \\
\text { factor }\end{array}$ \\
\hline $\begin{array}{l}\text { Crude surface protein } \\
\begin{array}{c}\text { BSM-agarose purified } \\
\text { protein (Pool A) }\end{array}\end{array}$ & 2.5 & 1.050 & 800 & 762 & 1 \\
& 0.5 & 0.052 & 320 & 6153 & 8.1 \\
\hline
\end{tabular}

*One unit of haemagglutinin (HA) activity was defined as the amount of protein required to give one well of haemagglutination. ${ }^{18}$

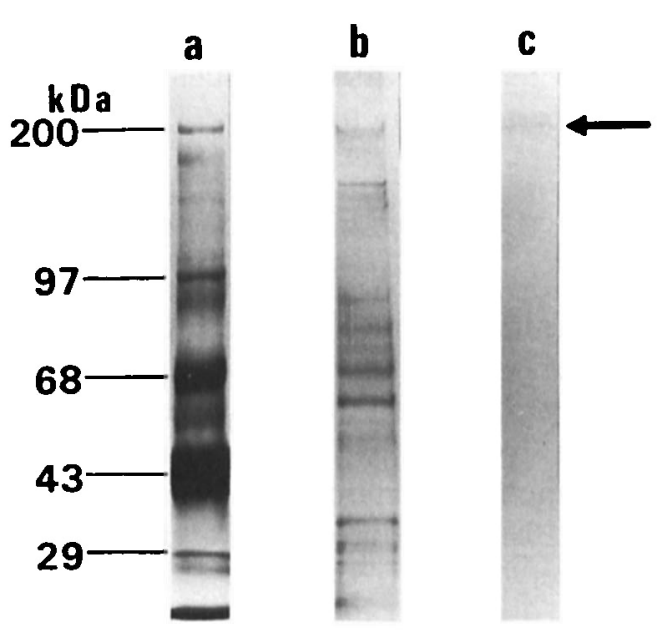

Fig. 2. SDS-PAGE analysis of crude surface protein and BSMagarose purified $200-\mathrm{kDa}$ protein. The numbers indicate the sizes of the molecular mass markers. Lanes: a, molecular mass markers; b, crude protein $(10 \mu \mathrm{g}) ; \mathbf{c}$, BSM-agarose purified protein $(1 \mu \mathrm{g})$. The gel was silver stained.

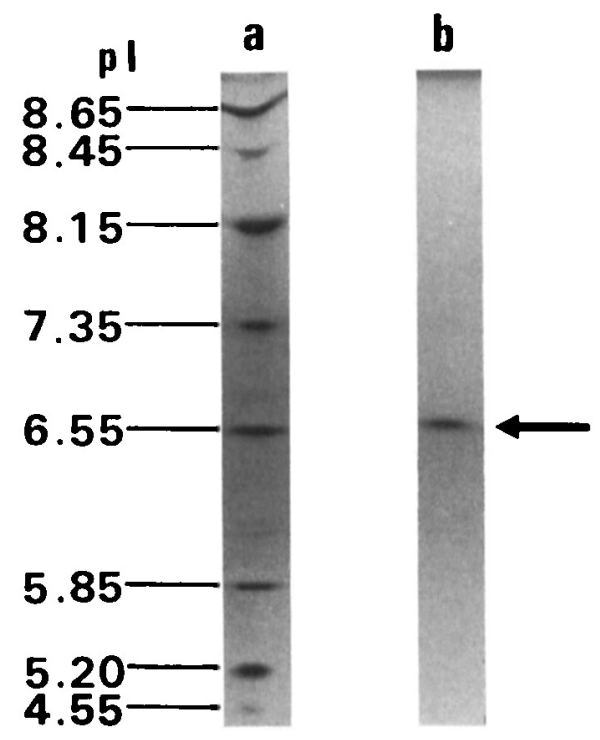

Fig. 3. Iso-electric focusing analysis of BSM-agarose purified protein. Lanes: a, iso-electric focusing markers; b, BSM-agarose purified protein. The gel was silver stained.

detected in only five fractions, numbers $128-132$. These fractions, which were obtained under the same eluting conditions, were used as pooled fraction A.

The crude protein extract and purified pooled fraction A were compared with respect to the specific activity of HA (table I). The specific activity of purified pooled fraction A was 6153 units/mg, which was 8.1 times that of the crude protein $(762 \mathrm{units} / \mathrm{mg})$.
Table II. Inhibition of adherence of $\boldsymbol{B}$. bronchiseptica strain M-3 to rat lung cell line (L2) by purified haemagglutinin

\begin{tabular}{ccc}
\hline $\begin{array}{c}\text { Haemagglutinin } \\
(\mu \mathrm{g})\end{array}$ & $\begin{array}{c}\text { Mean (SD) } \\
\text { adherence* }\end{array}$ & $\begin{array}{c}\text { Inhibition } \\
(\%)\end{array}$ \\
\hline None & $17.8(0.5)$ & 0 \\
1 & $13.2(0.4)$ & 26 \\
5 & $7.2(0.4)$ & 60 \\
10 & $2.9(0.3)$ & 84
\end{tabular}

*Mean number of bacteria attached/L2 cell and SD of the mean determined from triplicate assays.

Table III. Effect of pre-treatment of haemagglutinin with $N$ acetylneuraminic acid on adherence of $B$. bronchiseptica strain M-3 to rat lung cell line (L2)

\begin{tabular}{cr}
\hline $\begin{array}{c}\text { Haemagglutinin } \\
\text { treatment }\end{array}$ & $\begin{array}{c}\text { Mean (SD) } \\
\text { adherence* }\end{array}$ \\
\hline No haemagglutinin & $17 \cdot 8(0 \cdot 5)$ \\
Haemagglutinin $10 \mu$ g plus & \\
$N$-acetylneuraminic acid (mg) & $14 \cdot 5(0 \cdot 8)$ \\
10 & $6 \cdot 2(0 \cdot 2)$ \\
1 & $4 \cdot 8(0 \cdot 3)$ \\
$0 \cdot 1$ & $3 \cdot 1(0 \cdot 4)$ \\
0 & \\
\hline
\end{tabular}

*See footnote to table II.

\section{Electrophoretic analysis of the purified protein}

The purity, mol. wt and iso-electric point of the purified protein were determined by electrophoresis. The results of SDS-PAGE analysis are shown in fig. 2. After silver staining, the crude protein extract showed $>10$ bands between 200 and $29 \mathrm{kDa}$, whereas the purified protein showed only a single band at $200 \mathrm{kDa}$. The iso-electric point of the purified protein was pI 6.5 (fig. 3).

\section{Effect of the purified protein on adherence}

The effect of the purified protein on the adherence of $B$. bronchiseptica to $\mathrm{L} 2$ cells was examined in adherence inhibition assays. As shown in table II, pretreatment of the L2 cells with the purified protein resulted in a marked dose-dependent decrease in adherence of the organisms.

\section{Effect of NeuAc on binding of purified protein to L2 cells}

The binding specificity of the purified protein was examined in a competitive assay. The purified protein 
was treated with NeuAc and allowed to react with the L2 cells prior to examining the adherence of $B$. bronchiseptica. When the amount of NeuAc was increased, with a fixed amount of purified protein, the adherence of the organism was clearly increased (table III).

\section{Discussion}

The establishment of $B$. bronchiseptica infection requires adherence of the organism to epithelial cells in the respiratory tract for colonisation and proliferation. The receptors involved in this adherence have been found to contain sialic acid. ${ }^{17}$ However, there has been no report on the purification or properties of the adhesin of this organism. We assumed that the adhesin was a protein with lectin-like properties and attempted to purify it in one step by affinity chromatography with sialic acid as the ligand. Since sialic acid does not bind readily to agarose, bovine submaxillary mucin, which has an amino group and a high content of sialic acid, was used for binding studies. For elution in affinity chromatography, the conditions used by Ravindranath et $_{\text {al }}{ }^{18}$ to purify sialic acid-specific lectin from the serum of Cancer antennarius was employed. HA activity against bovine erythrocytes was observed in the fractions obtained by affinity chromatography

\section{References}

1. Andersson B, Dahmen $\mathbf{J}$, Frejd $\mathbf{T}$ et al. Identification of an active disaccharide unit of a glycoconjugate receptor for pneumococci attaching to human pharyngeal epithelial cells. J Exp Med 1983; 158: 559-570.

2. Andersson B, Porras O, Hanson LA, Lagergárd T, SwanborgEdén C. Inhibition of attachment of Streptococcus pneumoniae and Haemophilus influenzae by human milk and receptor oligosaccharides. J Infect Dis 1986; 153: 232-237.

3. Jones WG, Freter R. Adhesive properties of Vibrio cholerae: nature of the interaction with isolated rabbit brush border membranes and human erythrocytes. Infect Immun 1976; 14: $240-245$.

4. Krivan HC, Roberts DD, Ginsburg V. Many pulmonary pathogenic bacteria bind specifically to the carbohydrate sequence GalNAc $\beta 1-4 \mathrm{Gal}$ found in some glycolipids. Proc Nat Acad Sci USA 1988; 85: 6157-6161.

5. Lai C-H, Bloomquist C, Liljemark WF. Purification and characterization of an outer membrane protein adhesin from Haemophilus parainfluenzae HP-28. Infect Immun 1990; 58: 3833-3839.

6. Loomes LM, Uemura K, Childs RA et al. Erythrocyte receptors for Mycoplasma pneumoniae are sialylated oligosaccharides of Ii antigen type. Nature $1984 ; 307: 560-563$.

7. McSweegan E, Walker RI. Identification and characterization of two Campylobacter jejuni adhesins for cellular and mucous substrates. Infect Immun 1986; 53: 141-148.

8. Parkkinen J, Rogers GN, Korhonen T, Dahr W, Finne J. Identification of the O-linked sialyloligosaccharides of glycophorin A as the erythrocyte receptors for S-fimbriated Escherichia coli. Infect Immun 1986; 54: 37-42.

9. Plotkin BJ, Bemis DA. Adherence of Bordetella bronchiseptica to hamster lung fibroblasts. Infect Immun 1984; 46: 697-702.

10. Smit H, Gaastra W, Kamerling JP, Vliegenthart JFG, de Graaf FK. Isolation and structural characterization of the equine erythrocyte receptor for enterotoxigenic Escherichia coli K99 fimbrial adhesin. Infect Immun 1984; 46: 578-584. after heating at $32^{\circ} \mathrm{C}$ and with $0.05 \mathrm{M}$ Tris- $\mathrm{HCl}$ buffer, $\mathrm{pH} 7.5$, containing $0.3 \mathrm{M} \mathrm{NaCl}$ and $2 \mathrm{~mm}$ EDTA as the eluent. The specific activity of the HA was approximately eight times greater than that in the starting material. Electrophoretic analysis revealed that a protein of $200 \mathrm{kDa}$ with an iso-electric point of pI 6.5 had been purified in one step by affinity chromatography. Kimura et al. ${ }^{25}$ reported that the filamentous haemagglutinin (FHA) of $B$. pertussis was a protein with a mol. wt identical to that of the HA of B. bronchiseptica demonstrated in this study. Further evidence of a relationship between these proteins was provided by Domenighini et al. ${ }^{26}$ who observed crossreactions with antibody to the recombinant FHA of $B$. pertussis, providing evidence for the presence of an FHA in B. bronchiseptica.

The adhesin activity of the purified HA was also assayed. An adherence inhibition assay of B. bronchiseptica was performed with the L2 line of rat lung epithelial cells. Treatment of $L 2$ cells with HA resulted in a marked decrease in the adherence of the organisms. However, bacterial adherence was not prevented when HA was allowed to react with NeuAc before treatment of the L2 cell line. These findings indicated that HA was able to bind specifically to sialic acid in the cell membrane. In conclusion, the HA of $B$. bronchiseptica acts as an adhesin and probably plays a key role in the pathogenesis of infection by this organism.

11. Ishikawa $\mathbf{H}$, Isayama $\mathrm{Y}$. Effect of antigenic modulation and phase variation on adherence of Bordetella bronchiseptica to porcine nasal epithelial cells. Am J Vet Res 1987; 48: 1689-1691.

12. Ishikawa $\mathbf{H}$, Isayama $Y$. Bovine erythrocyte-agglutinin as a possible adhesin of Bordetella bronchiseptica responsible for binding to porcine nasal epithelium. $J$ Med Microbiol 1988; 25: 205-209.

13. Relman DA, Domenighini M, Tuomanen E, Rappuoli R, Falkow S. Filamentous hemagglutinin of Bordetella pertussis: Nucleotide sequence and crucial role in adherence. Proc Nat Acad Sci USA 1989; 86: 2637-2641.

14. Tuomanen E, Weiss A. Characterization of two adhesins of Bordetella pertussis for human ciliated respiratoryepithelial cells. J Infect Dis 1985; 152: 118-125.

15. Leininger E, Roberts M, Kenimer JG. Pertactin, an Arg-GlyAsp-containing Bordetella pertussis surface protein that promotes adherence of mammalian cells. Proc Nat Acad Sci USA 1991; 88: 345-349.

16. Ashworth LA, Robinson A et al. Agglutinogens and fimbriae of Bordetella pertussis. Tokai J Exp Clin Med 1988; 13: 203-210.

17. Ishikawa $H$, Isayama $Y$. Evidence for sialyl glycoconjugates as receptors for Bordetella bronchiseptica on swine nasal mucosa. Infect Immun 1987; 55: 1607-1609.

18. Ravindranath MH, Higa HH, Cooper EL, Paulson JC. Purification and characterization of an $O$-acetylsialic acidspecific lectin from a marine crab Cancer antennarius. $J$ Biol Chem 1985; 260: 8850-8856.

19. Sakurai Y, Suzuki H, Kobayashi N, Terada E, Takakura A, Kagiyama N. Determination of an antigen suitable for enzyme-linked immunosorbent assay of the antibody to Bordetella bronchiseptica in guinea pigs. Exp Anim 1990; 39: 549-555.

20. Goel MC. New method for the isolation of membranes from Mycoplasma gallisepticum. $J$ Bacteriol 1973; 116: 994-1000.

21. Hovowitz SA, Cassell GH. Detection of antibodies to Mycoplasma pulmonis by an enzyme-linked immunosorbent assay. Infect Immun 1978; 22: 161-170. 
22. Lowry HO, Rosebrough NJ et al. Protein measurement with the folin phenol reagent. $J$ Biol Chem 1951; 193: 265-275.

23. Laemmli UK. Cleavage of structual proteins during the assembly of the head of bacteriophage T4. Nature 1970; 227: $680-685$.

24. Catsimpoolas N. Micro isoelectric focusing in polyacrylamide gel columns. Anal Biochem 1968; 26: 480-482.

25. Kimura A, Mountzouros KT, Relman DA, Falkow S, Cowell
JL. Bordetella pertussis filamentous hemagglutinin: Evaluation as a protective antigen and colonization factor in a mouse respiratory infection model. Infect Immun 1990; 58: $7-16$.

26. Domenighini M, Relman D, Capian C et al. Genetic characterization of Bordetella pertussis filamentous haemagglutinin: a protein processed from an unusually large precursor. $\mathrm{Mol}$ Microbiol 1990; 4: 787-800. 